\title{
Correction to: Durability Properties of Alkali Activated Slag Composites: Short Overview
}

\section{Paul Awoyera ${ }^{1} \cdot$ Adeyemi Adesina $^{2}$}

Published online: 8 April 2020

(C) Springer Nature B.V. 2020

\section{Correction to: Silicon}

https://doi.org/10.1007/s12633-019-00199-1

The original version of this paper was unfortunately published as a book review, when it is a review article. The correct article type has been well stated above.

Publisher's Note Springer Nature remains neutral with regard to jurisdictional claims in published maps and institutional affiliations.

The online version of the original article can be found at https://doi.org/ 10.1007/s12633-019-00199-1

$\triangle$ Paul Awoyera

paul.awoyera@covenantuniversity.edu.ng

1 Department of Civil Engineering, Covenant University, Ota, Nigeria

2 University of Windsor, Windsor, Canada 